\title{
Intentional Diversity
}

\section{Program Ideas from the Field}

\author{
COMPILED BY AFRICA HANDS
}

$\mathrm{T}$ he year 2014 was a watershed one for bringing awareness to the issue of diversity in children's literature. The late author Walter Dean Myers wrote a stirring opinion piece for the New York Times ${ }^{1}$ about the Cooperative Children's Book Center's (CCBC) report revealing that of the thirty-two-hundred children's books published in 2013, only ninety-three were about black people. ${ }^{2}$

Even fewer books were published about American Indians, Asian and Pacific Islanders, and Latinos. Myers' son, author Christopher Myers, also penned a piece about what he called the "apartheid" of literature-the relegation of characters of color to historical texts rather than portraying characters as members of contemporary society facing real-world issues. In addition to books featuring diverse characters acting as mirrors through which readers see themselves, the younger Myers regards diverse books as maps that help readers navigate the world. ${ }^{3}$ In today's publishing landscape, children of color; children with disabilities; and children with same-gender parents, single parents, or grandparents as parents have very few maps.

Also in 2014, we witnessed the birth of an energetic new initiative highlighting the lack of and need for diverse characters in youth literature-We Need Diverse Books. What began as hashtag advocacy on Twitter is now an incorporated nonprofit organization led by children and young adult authors and library professionals. ${ }^{4}$ The organization has effected change at large book events like BookCon, making diversity in youth literature a conversation for the main stage at conferences.

Diversifying the books we recommend to young patrons is not a difficult task. There are quality books featuring diverse characters available today, though certainly not as many as books that feature white characters. Diversifying our collections and programs requires intentionality. It requires librarians and library staff intentionally taking the time, when designing programs and creating booklists, to ask: "Who is missing?," "Who haven't we seen in our library?," and "What other perspectives can we bring to this program?" If needed, create a diversity cheat sheet to help you remember the spectrum of patrons in your community. If all else fails, borrow ideas from other libraries.

The programs listed here, submitted by ALSC members, illustrate how diverse voices have been successfully incorporated. Admittedly, most of these programs deal with racial and ethnic diversity; however, your library's diversity efforts needn't

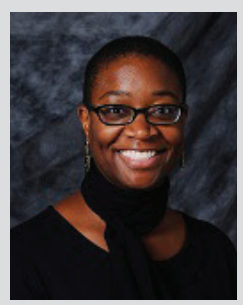

Africa Hands is a contract librarian in Louisville, Kentucky. She is the author of Successfully Serving the College Bound (ALA Editions, 2015) and chair of the ALSC Library Services to Special Population Children and Their Caregivers Committee. You can find her sharing news and resources related to youth services and higher education on Twitter @africahands. 


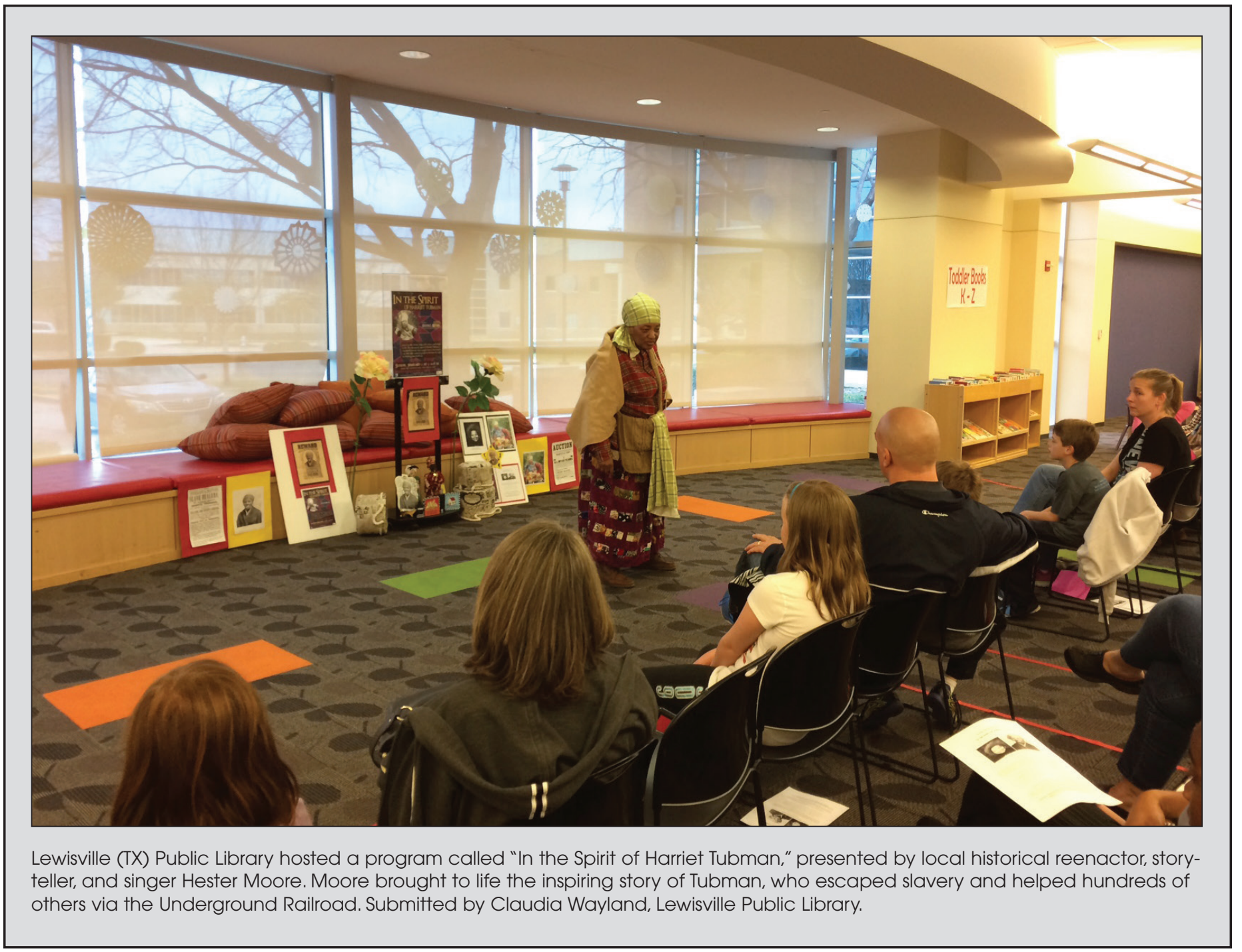

be limited in this way. Children with disabilities, non-native English speakers, LGBT children and families, children with an incarcerated family member, and children in nontraditional school settings are also part of the diversity spectrum.

\section{Author Panel}

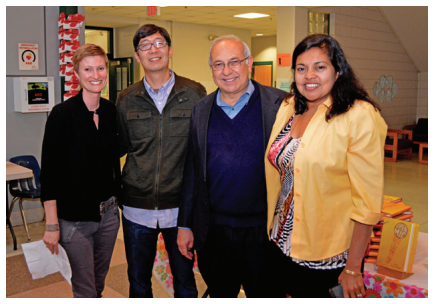

As part of its Big Read program, Reading (MA) Public Library hosted an author panel featuring multicultural contributors to the book Open Mic: Riffs on Life Between Cultures in Ten Voices (Candlewick Press, 2013). The panel, which took place at a local middle school, included a book signing and a question-and-answer session with the authors. Author Mitali Perkins also conducted writing workshops with students. The library, with support from Candlewick Press, the local high school, and the Big Read program, was able to purchase books for each ninth-grade classroom, along with discussion guides so the book can be used as part of the freshman curriculum. Submitted by Andrea Fiorillo, Renee Smith, and Susan Beauregard, Reading Public Library.

\section{Book Discussion}

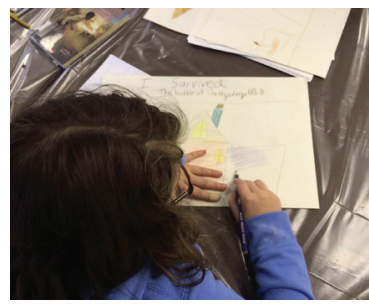

Gold Coast Public Library in New York offers a book discussion program, Reader Artists, which incorporates literature and art to students in first through sixth grades. Children choose one book, from a selection of three, to read and discuss with the group. The young readers discuss characters and the issues faced in the book then create an art piece representative of the book. Librarian Dina Schuldner adds diversity to the program by including books with African American characters. For example, for the discussion on the Civil War, readers selected either I Survived: The Battle of Gettysburg, 1863 (Scholastic, 2013) or A New Beginning: My Journey with 
Addy (American Girl, 2014). Books with characters of color can be added to non-historical themes as well. Submitted by Dina Schuldner, Gold Coast Public Library.

\section{School Visit}

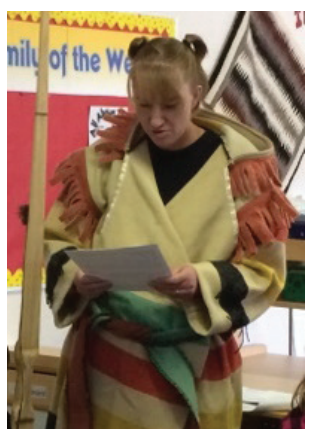

With funding from the LSTA Indigenous People's grant, librarians at Richfield (UT) Public Library visited the local Head Start to present a program on American Indian tribes in the state. Using props like bows, antlers, willow sticks, and cloaks, a reader's theatre was adapted from Pushing Up the Sky (Dial, 2000) giving the children an opportunity to be involved in the storytelling. The school visit was part of the library's effort to increase programming for American Indian families who live in the community. Submitted by Robin Davis, Richfield Public Library.

\section{Local and National Tie-Ins}

Local and national events portrayed in the news provide plenty of ideas for diverse programming and opportunities for discussion of contemporary issues. Following the defacing of a statue of African American baseball Hall of Famer Jackie Robinson, Julie Marie Frye (then school librarian at Spring Mill Elementary School in Indianapolis), posted pictures and questions about the incident throughout the library giving fourth and fifth grade students an opportunity to reflect on the crime. Frye received approximately sixty responses from students addressing why the defacing happened, how Robinson would have responded to the crime, and what should be done to the perpetrators. Later in the year, Robinson's daughter, Sharon, visited the school for more discussion.

In response to news about national immigration policies, Frye engaged fifth-grade students in a card sort activity wherein students prioritized factors that should be considered when evaluating immigration applications. The students' responses did not align with the nation's policies, so they created projects that "spoke back" to government immigration policies. Frye consulted with Ben Mikaelsen, author of Red Midnight (HarperCollins, 2002), to help shape the project. Submitted by Julie Marie Frye, formerly at Spring Mill Elementary School.

\section{Celebrating a Holiday}

Librarians are always looking for ways to commemorate holi-

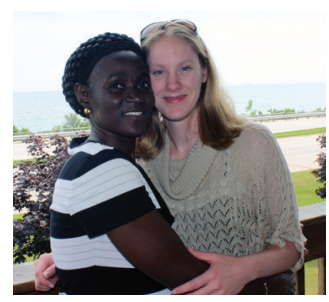
days. These special days are perfect for adding diverse voices to programming. In celebration of Earth Day this year, Brown County (WI) Central Library hosted Miranda Paul, author of One Plastic Bag: Isatou Ceesay and the Recycling Women of the Gambia (Lerner/Millbrook, 2015). Paul, a board

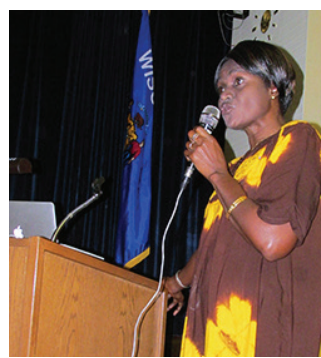
member of We Need Diverse Books, appeared with Ceesay, the inspiration for her book, who traveled to the United States from Africa. Together, the women talked to about 150 elementary school children about creative ways to address environmental issues. They also offered a writing workshop and displayed Ceesay's purses made from

\section{Additional Resources on Diversity}

A Cheat Sheet for Selling Diversity by Grace Lin, www.gracelin.com/media/press/diversitycheatsheet.pdf

ALA Public Programs Office, ala.org/news/taxonomy/term/624

Disability in Kidlit, http://disabilityinkidlit.com/

Institute of Museum and Library Services grants, imls.gov/applicants/default.aspx

Library Services to Special Population Children and Their Caregivers-ALSC blog posts, alsc.ala.org/blog/author/lsspcc

- Library Services to Special Population Children and Their Caregivers: A Toolkit for Librarians and Library Workers, ala.org/alsc/sites/ ala.org.alsc/files/content/professional-tools/lsspcc-toolkit-2015.pdf

- National Endowment for the Arts: The Big Read, http://neabigread.org

National Endowment for the Humanities grants, www.neh.gov/grants/match-your-project

The Libri Foundation grants, www.librifoundation.org/apps.html

We Need Diverse Books, http://weneeddiversebooks.org/ 
discarded plastic bags. Submitted by Sharon Verbeten, Brown County Central Library.

\section{Using Staff Resources}

While it is great to host diverse guest speakers and authors, sometimes library staff can participate in programs based on their personal experience and cultural background. After successfully organizing Native American heritage month and Chinese New Year celebrations, staff at Pasadena (TX) Public Library created an International Festival. Several staff members were raised outside the United States, so each month a staff member presented a cultural program on his or her home country. Programs included stories, crafts, and snacks from different countries. Submitted by Hui Zhang, Pasadena Public Library.

The time has long come for libraries to normalize diversity through intentionally inclusive programs, booklists, and displays. When children and families of diverse backgrounds see themselves and their experiences reflected in our programs, a new world opens-one that honors their experiences, one with a proper map, one that unabashedly says, "We see you." And, in the process, we help others see them as well.

\section{References}

1. Walter Dean Myers, "Where Are the People of Color in Children's Books?," New York Times, March 15, 2014, accessed April 13, 2015, www.nytimes.com/2014/03/16/ opinion/sunday/where-are-the-people-of-color-in -childrens-books.html?_r=1.

2. Cooperative Children's Book Center, University of Wisconsin-Madison, "Children's Books by and about People of Color Published in the United States," accessed April 13, 2015, http://ccbc.education.wisc.edu/books/ pcstats.asp.

3. Christopher Myers, "The Apartheid of Children's Literature," New York Times, March 15, 2014, accessed April 14, 2015, www.nytimes.com/2014/03/16/opinion/ sunday/the-apartheid-of-childrens-literature.html.

4. We Need Diverse Books, "Annual Report, 2014," accessed April 15, 2015, http:/ /weneeddiversebooks.org/ annualreport2014.

\section{Many thanks 2015 Newbery-Caldecott-Wilder Banquet Gold Sponsors!}

BOT (Books on Tape)

Candlewick Press

HarperCollins Children's Books

Houghton Mifflin Harcourt

Kwame Alexander's Book-In-a-day (BID) Little, Brown Books for Young Readers

Penguin Young Readers

Random House Children's Books 